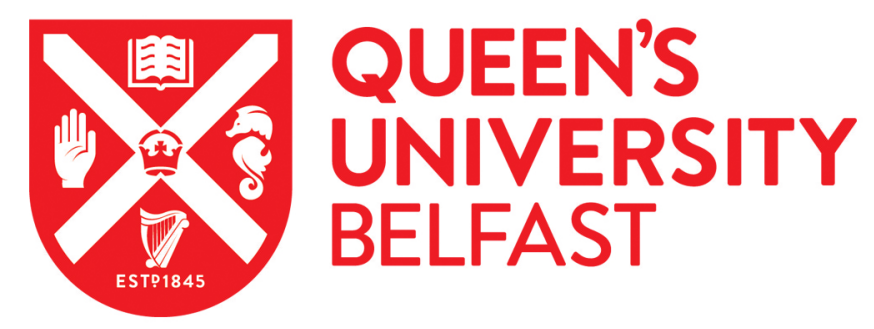

\title{
Arbuscular mycorrhizal fungi associated with the Meliaceae on Hainan island, China
}

Shi, Z. Y., Chen, Y. L., Feng, G., Liu, R. J., Christie, P., \& Li, X. L. (2006). Arbuscular mycorrhizal fungi associated with the Meliaceae on Hainan island, China. Mycorrhiza, 16(2), 81-87.

https://doi.org/10.1007/s00572-005-0017-6

\section{Published in:}

Mycorrhiza

Queen's University Belfast - Research Portal:

Link to publication record in Queen's University Belfast Research Portal

\section{General rights}

Copyright for the publications made accessible via the Queen's University Belfast Research Portal is retained by the author(s) and / or other copyright owners and it is a condition of accessing these publications that users recognise and abide by the legal requirements associated with these rights.

Take down policy

The Research Portal is Queen's institutional repository that provides access to Queen's research output. Every effort has been made to ensure that content in the Research Portal does not infringe any person's rights, or applicable UK laws. If you discover content in the Research Portal that you believe breaches copyright or violates any law, please contact openaccess@qub.ac.uk. 


\section{Arbuscular mycorrhizal fungi associated with the Meliaceae on Hainan island, China}

Received: 22 December 2004 / Accepted: 8 July 2005 / Published online: 17 August 2005

(C) Springer-Verlag 2005

\begin{abstract}
Species richness, spore density, frequency of occurrence, and relative abundance of AM fungi were determined in rhizosphere soil samples from nine tropical rainforest sites on Hainan island, south China, and the arbuscular mycorrhizal (AM) status of members of the Meliaceae was examined. All 28 plant taxa investigated (25 species including two varieties of 1 species and three varieties of another) were colonized by AM fungi. The mean proportion of root length colonized was 56\% (range $10-95 \%$ ). Vesicles were observed in 27 and hyphal coils in 26 of the 28 plant taxa. Mycorrhizas were of the Paristype or intermediate-type, with no Arum-type mycorrhizas observed. Species richness of AM fungi varied from 3 to 15 and spore density from 46 to 1,499 per 100 g rhizosphere soil. Of 33 AM fungal taxa in five genera isolated and identified, 18 belonged to Glomus, 9 to Acaulospora, 1 to Entrophospora, 2 to Gigaspora, and 3 to Scutellospora. Acaulospora and Glomus were the dominant genera
\end{abstract}

\author{
Z. Y. Shi · G. Feng · P. Christie · X. L. Li $(\bowtie)$ \\ College of Resources and Environmental Sciences, \\ China Agricultural University, \\ Beijing, 100094, China \\ e-mail: lixl@cau.edu.cn \\ Tel.: +86-10-62891352 \\ Fax: +86-10-62891016 \\ Y. L. Chen \\ Research Institute of Tropical Forestry, \\ Chinese Academy of Forestry, \\ Guangzhou, Guangdong, 510520, China \\ Y. L. Chen \\ School of Biological Sciences and Biotechnology, \\ Murdoch University, \\ Perth, WA, 6150, Australia \\ R. J. Liu \\ Mycorrhiza Laboratory, Laiyang Agricultural College, \\ Laiyang 265200, Shandong, China \\ P. Christie \\ Agricultural and Environmental Science Department, \\ Queen's University Belfast, \\ Newforge Lane, \\ Belfast BT9 PX, UK
}

identified. Glomus claroideum was the taxon most commonly isolated, with a frequency of occurrence of $56.5 \%$ and relative abundance of $10.4 \%$. A positive correlation was found between percentage of root length colonization and species richness. However, there was no correlation between spore density and percentage of root length colonized by AM fungi.

Keywords Tropical AM fungal diversity - Arbuscular mycorrhiza $\cdot$ Meliaceae $\cdot$ Spore density

\section{Introduction}

The Meliaceae are a pantropical plant family whose distribution is centered in Asia and Africa. In China, the family is distributed mainly in the southwest and the south of the country (Chen 1995). The Meliaceae are one of the most important tree families in tropical rain forests both ecologically and economically. Some trees are a major source of very valuable tropical hardwood timber such as mahogany, and members of the family are also used for oil, soap manufacture, insecticides, and medicines (Cheplogoi and Mulholland 2003; Omar et al. 2003).

Arbuscular mycorrhizal (AM) fungi evolved concurrently with the first colonization of land by plants some 450 to 500 million years ago and persist in most extant plant taxa (Cairney 2000). The associations formed between plant roots and AM fungi are of great interest because of their potential influence on ecosystem processes, their role in determining plant diversity in natural communities, and the capacity of AM fungi to induce a wide variety of growth responses in coexisting plant species (Sanders et al. 1996; van der Heijden et al. 1998a,b; Hartnett and Wilson 1999; Klironomos et al. 2000). AM associations are widespread, occurring in the roots of most angiosperms and pteridophytes, along with some gymnosperms and the gametophytes of some lower plants such as mosses and lycopods (Smith and Read 1997). Recent studies have indicated that AM fungi are common and ecologically important in tropical ecosystems, and that cooccurring plant 
species vary considerably in their germination, growth, and flowering responses to mycorrhizal colonization along a continuum from highly responsive obligately mycotrophic species to facultatively mycotrophic and nonresponsive species (Johnson et al. 1997; Muthukumar et al. 2003). Tropical rain forests display high plant species diversity and complex community structure (Read 1994).

In recent years, there has been increasing interest in the arbuscular mycorrhizae of tropical rain forest plants (Guadarrama and Alvarez-Sanchez 1999; Muthukumar et al. 2003; Tawaraya et al. 2003; Zhao 2000; Zhao et al. 2001). However, according to Brundrett et al. (1995) and Wubeta et al. (2003), apart from a few fragmented reports, there have been no investigations reported on arbuscular mycorrhizae of the family Meliaceae.

The present study was carried out to better understand the arbuscular mycorrhizal status of this important tree family. We conducted a systematic investigation of arbuscular mycorrhizae of Meliaceae based on a broad field survey from 2001 to 2002 on tropical Hainan island, a province located off the south coast of mainland China.

\section{Materials and methods}

Study sites

Hainan island lies in the tropical oceanic monsoon climatic zone, with an annual mean temperature range of $22-26^{\circ} \mathrm{C}$ and annual rainfall of $1,600 \mathrm{~mm}$. There is a clear demarcation between the rainy season from May to October and the dry season from November to April, with $80 \%$ of the annual rainfall occurring during the rainy season. More than 300 days each year are classed as sunny. The samples were collected from nine sites, namely, Xinglong, Mount Wuzhi, Mount Diaoluo, Baoting, Maoyang, Jianfengling Forestry Centre, Mount Bawang, Bawangling Forestry Centre, and Danzhou (Table 1).

Physical and chemical analysis of soil samples

Selected properties of the soils at the sites (listed in the same sequence as above) were $\mathrm{pH}\left(\mathrm{H}_{2} \mathrm{O}, 1: 5\right.$ soil/water

Table 1 Description of sampling sites

\begin{tabular}{|c|c|c|c|c|}
\hline $\begin{array}{l}\text { Sampling site } \\
\text { and elevation }\end{array}$ & Species of Meliaceae present & Soil type & Vegetation type & $\begin{array}{l}\text { Site latitude } \\
\text { and longitude }\end{array}$ \\
\hline Xinglong $(184 \mathrm{~m})$ & $\begin{array}{l}\text { Aglaia roxburghiana Miq.; Swietenia mahagoni (L.) Jacq.; } \\
\text { Trichilia sinensis Bentv. }\end{array}$ & I-Lithosols & $\begin{array}{l}\text { Tropical evergreen } \\
\text { forest (plantation) }\end{array}$ & $\begin{array}{l}18^{\circ} 1.03^{\prime} \mathrm{N} \\
110^{\circ} 13.04^{\prime} \mathrm{E}\end{array}$ \\
\hline $\begin{array}{l}\text { Mount Wuzhi } \\
(850 \mathrm{~m})\end{array}$ & $\begin{array}{l}\text { Aphanamixis grandiflora Bl.; Aphanamixis polystachya (Wall.) } \\
\text { R.N. Parker; Chukrasia tabularis A. Juss. var. microcarp (Pierre) } \\
\text { Pellegrin; Melia azadirachta L.; Swietenia mahagoni (L.) Jacq.; } \\
\text { Xylocarpus granatum Koen. }\end{array}$ & I-Lithosols & $\begin{array}{l}\text { Tropical evergreen } \\
\text { forest }\end{array}$ & $\begin{array}{l}18^{\circ} 48.37^{\prime} \mathrm{N} \\
109^{\circ} 46.12^{\prime} \mathrm{E}\end{array}$ \\
\hline $\begin{array}{l}\text { Mount Diaoluo } \\
(1,280 \mathrm{~m})\end{array}$ & $\begin{array}{l}\text { Aphanamixis polystachya (Wall.) R.N.Parker; Swietenia } \\
\text { macrophylla King; Swietenia mahagoni (L.) Jacq. }\end{array}$ & I-Lithosols & $\begin{array}{l}\text { Tropical evergreen } \\
\text { forest }\end{array}$ & $\begin{array}{l}18^{\circ} 44.31^{\prime} \mathrm{N} \\
109^{\circ} 41.03^{\prime} \mathrm{E}\end{array}$ \\
\hline Baoting $(658 \mathrm{~m})$ & $\begin{array}{l}\text { Amoora tetrapetala (Pierre) C.Y. Wu; Dysoxylum binectariferum } \\
\text { Hook.f. ex Bedd.; Dysoxylum lukii Merr., How \& T.C. Chen; } \\
\text { Munronia hainanensis How \& T.C. Chen; Munronia simplicifolia } \\
\text { Merr.; Swietenia mahagoni (L.) Jacq. }\end{array}$ & I-Lithosols & $\begin{array}{l}\text { Tropical evergreen } \\
\text { forest (plantation) }\end{array}$ & $\begin{array}{l}19^{\circ} 5.02^{\prime} \mathrm{N} \\
109^{\circ} 4.25^{\prime} \mathrm{E}\end{array}$ \\
\hline $\begin{array}{l}\text { Mount Bawang } \\
(930 \mathrm{~m})\end{array}$ & Swietenia mahagoni (L.) Jacq.; Swietenia macrophylla King & $\begin{array}{l}\text { Ao-Orthic } \\
\text { Acrisols }\end{array}$ & $\begin{array}{l}\text { Tropical evergreen } \\
\text { forest }\end{array}$ & $\begin{array}{c}109^{\circ} 18.23^{\prime} \mathrm{E} \\
19^{\circ} 4.52^{\prime} \mathrm{N}\end{array}$ \\
\hline
\end{tabular}


ratio) $5.32,4.19,5.77,5.71,6.71,6.04,4.79,6.87$, and 6.19 units; organic matter content (Schollenberger method) $3.06,3.27,2.84,2.48,3.00,2.15,1.75,3.97$, and $2.40 \%$; available P (Olsen method) 33.0, 11.8, 10.7, 30.0, 17.7, $11.9,7.3,11.6$, and $11.5 \mathrm{mg} \mathrm{kg}^{-1}$; available $\mathrm{N}$ (alkali hydrolysis diffusion method) 57.6, 138.3, 96.5, 56.2, 79.2, 53.3, 46.1, 95.1, and $80.7 \mathrm{mg} \mathrm{kg}$; ; and available $\mathrm{K}$ (extracted with $\mathrm{NH}_{4} \mathrm{AcO}$ ) 89.9, 87.9, 98.0, 106.0, 119.0, $143.0,90.9,122.0$, and $78.9 \mathrm{mg} \mathrm{kg}^{-1}$.

Collection of soil and root samples

Surface soil (approximately 1-2 $\mathrm{mm}$ ) was removed, and soil cores of 0 to $50 \mathrm{~cm}$ were collected including fine roots and rhizosphere soils of the host plants. Root samples were collected from a total of 25 species including three varieties of 1 species and two varieties of another species, giving a total of 28 taxa within the Meliaceae (Table 1). Roots were traced back to the stem of the host plants to ensure that the roots were indeed connected to the plants selected for sampling. Three rooting-zone soil samples (each approximately $1,000 \mathrm{~g}$ ) with fine roots were collected in three different directions from each plant, and the three samples were mixed thoroughly. A subsample of approximately $500 \mathrm{~g}$ was then taken for assessment of AM fungal colonization and extraction of AM fungal spores. Six individuals of each plant species or variety were randomly selected for sampling of soil and roots.

\section{Assessment of AM colonization}

Fresh roots (approximately $0.2 \mathrm{~g}$ ) were processed by washing them free of soil and clearing in $10 \%(\mathrm{w} / \mathrm{v}) \mathrm{KOH}$ at $90^{\circ} \mathrm{C}$ in a water bath for $30-60 \mathrm{~min}$, the exact time

Table 2 Arbuscular mycorrhizal (AM) status of roots of Meliaceae on Hainan island

\begin{tabular}{|c|c|c|c|c|c|c|}
\hline Host plant species & $\begin{array}{l}\text { Percent root length } \\
\text { colonized }\end{array}$ & $\begin{array}{l}\text { Spore density per } \\
100 \mathrm{~g} \text { soil }\end{array}$ & Vesicles & Arbuscules & $\begin{array}{l}\text { Hyphal } \\
\text { coils }\end{array}$ & $\begin{array}{l}\text { Species } \\
\text { richness }\end{array}$ \\
\hline Aglaia roxburghiana Miq. & $40 \mathrm{de}$ & $365 \mathrm{f}$ & ++ & + & ++ & $5.17 \mathrm{f}$ \\
\hline Amoora tetrapetala (Pierre) C.Y.Wu & 30 e & $188 \mathrm{hi}$ & + & + & + & $5.33 \mathrm{fg}$ \\
\hline Amoora tsangii (Merr.) X.M.Chen & 20 ef & $139 \mathrm{ij}$ & + & + & - & 5.83 ef \\
\hline Aphanamixis grandiflora $\mathrm{Bl}$. & 20 ef & $112 \mathrm{j}$ & + & - & + & 6.17 ef \\
\hline Chukrasia tabularis A. Juss. & $40 \mathrm{de}$ & $618 \mathrm{c}$ & +++ & - & ++ & $11.67 \mathrm{~b}$ \\
\hline $\begin{array}{l}\text { Chukrasia tabularis A. Juss. var. microcarp } \\
\text { (Pierre) Pellegrin }\end{array}$ & $60 \mathrm{c}$ & $436 \mathrm{e}$ & +++ & + & ++ & $9.33 \mathrm{c}$ \\
\hline $\begin{array}{l}\text { Chukrasia tabularis A. Juss. var. velutina } \\
\text { (Wall.) King }\end{array}$ & $85 \mathrm{ab}$ & $302 \mathrm{~g}$ & +++ & + & +++ & $8.33 \mathrm{~cd}$ \\
\hline Dysoxylum lukii Merr., How \& T.C.Chen & $60 \mathrm{c}$ & $318 \mathrm{~g}$ & ++ & - & + & $6.33 \mathrm{ef}$ \\
\hline $\begin{array}{l}\text { Dysoxylum mollissimum Bl. var. } \\
\text { glaberrimum P.Y. Chen }\end{array}$ & $85 \mathrm{ab}$ & $224 \mathrm{~h}$ & +++ & + & ++ & $6.50 \mathrm{e}$ \\
\hline Dysoxylum mollissimum B1. & $80 \mathrm{~b}$ & $207 \mathrm{~h}$ & ++ & + & + & $7.17 \mathrm{de}$ \\
\hline Khaya senegalensis (Desr.) A.Juss. & 95 a & $786 \mathrm{~b}$ & +++ & + & ++ & $11.83 \mathrm{~b}$ \\
\hline Melia azadirachta L. & 20 ef & $339 \mathrm{fg}$ & ++ & - & + & $7.50 \mathrm{de}$ \\
\hline Munronia hainanensis How \& T.C.Chen & $45 \mathrm{~d}$ & $319 \mathrm{~g}$ & ++ & - & ++ & $8.33 \mathrm{~cd}$ \\
\hline Munronia simplicifolia Merr. & 20 ef & $59 \mathrm{k}$ & + & - & + & $3.83 \mathrm{~g}$ \\
\hline Swietenia macrophylla King & $30 \mathrm{e}$ & $346 \mathrm{fg}$ & + & + & + & $8.50 \mathrm{~cd}$ \\
\hline Swietenia mahagoni (L.) Jacq. & $80 \mathrm{~b}$ & $104 \mathrm{j}$ & +++ & + & +++ & $6.33 \mathrm{ef}$ \\
\hline
\end{tabular}

Relative development of structures shown as +++ , always present in substantial numbers; ++ , always present; + , very rare; - , not detected. Values in columns followed by the same letter are not significantly different by LSD $(p>0.05)$ 
depending on the degree of lignification of the roots and their pigmentation. The cooled root samples were washed and cut into 0.5 to $1.0-\mathrm{cm}$-long segments and stained with $0.5 \%(\mathrm{w} / \mathrm{v})$ acid fuchsin (Biermann and Linderman 1981). Thirty root fragments (approximately $1 \mathrm{~cm}$ long) were mounted on slides in a polyvinyl alcohol-lactic acid-glycerol solution (Koske and Tessier 1983) and examined at 100-400× magnification under an Olympus BX50 microscope with an automatic photomicrographic system for the presence of AM fungal structures. The percentage of root length colonized by AM fungal structures was determined using the magnified line-intersect method of McGonigle et al. (1990). The hyphae, arbuscules, and vesicles were recorded when any of them were presented at an intersection.
Recovery and counting of AM fungal spores

Three soil samples were randomly selected from the six original samples. Spores or sporocarps were extracted from $100 \mathrm{~g}$ air-dried subsamples of each soil sample in triplicate by wet sieving followed by flotation-centrifugation in 50\% sucrose (Dalpe 1993). The finest sieve used was $53 \mu \mathrm{m}$. The spores were collected on a grid patterned $(4 \times 4 \mathrm{~mm})$ filter paper, washed three times with distilled water to spread them evenly over the entire grid, and counted using a dissecting microscope at $30 \times$ magnification. A sporocarp was counted as one unit. The number of spores is expressed as the mean of three replicates. For observation and identification of spore characters, spores

Table 3 Relative abundance (\%) and frequency of occurrence (\%) of AM fungal species in the rhizospheres of Meliaceae on Hainan island, China

\begin{tabular}{|c|c|c|c|}
\hline AM fungal species & Sporocarps & Relative abundance & Frequency of occurrence \\
\hline Acaulospora appendicola Spain, Sieverding \& N. C. Schenk & - & 2.9 & 26.8 \\
\hline Acaulospora denticulata Sieverd. \& S. Toro & - & 5.9 & 17.3 \\
\hline Acaulospora elegans Trappe \& Gerd. & - & 3.6 & 32.1 \\
\hline Acaulospora foveata Trappe \& Janos & - & 2.7 & 29.8 \\
\hline Acaulospora lacunose J.B. Morton & - & 2.8 & 20.8 \\
\hline Acaulospora rehmii Sieverd. \& S. Toro & - & 2.1 & 17.3 \\
\hline Acaulospora spinosa C. Walker \& Trappe & - & 5.0 & 41.7 \\
\hline Acaulospora sp. 1 & - & 0.7 & 10.1 \\
\hline Acaulospora sp. 2 & - & 1.3 & 11.3 \\
\hline Entrophospora sp. & - & 1.6 & 12.5 \\
\hline Glomus aggregatum N.C. Schenck \& G.S. Sm., emend. Koske & + & 4.5 & 36.9 \\
\hline Glomus caledonium (T.H. Nicolson \& Gerd.) Trappe \& Gerd. & - & 2.1 & 14.9 \\
\hline Glomus citricolum Tang \& Zang, & - & 1.1 & 6.0 \\
\hline Glomus claroideum N.C. Schenck \& G.S. Smith & - & 10.4 & 56.6 \\
\hline Glomus clarum T.H. Nicolson \& Gerd. & - & 4.1 & 19.6 \\
\hline Glomus constrictum Trappe & - & 1.9 & 14.3 \\
\hline Glomus deserticola Trappe, Bloss \& J.A. Menge & - & 2.4 & 22.0 \\
\hline Glomus dolichosporum Zhang \& Wang & - & 4.7 & 29.8 \\
\hline Glomus etunicatum W.N. Becker \& Gerd. & - & 9.9 & 53.0 \\
\hline Glomus glomerulatum Sieverd. & + & 1.7 & 15.5 \\
\hline Glomus intraradices N.C. Schenck \& G.S. Sm. & - & 2.2 & 19.1 \\
\hline Glomus macrocarpum Gerd. \& Trappe & - & 5.7 & 32.7 \\
\hline Glomus microcarpum Tul. \& C. Tul. & - & 3.3 & 31.6 \\
\hline Glomus mosseae (T.H. Nicoson \& Gerd.) Gerd. \& Trappe & - & 5.1 & 29.8 \\
\hline Glomus versiforme (P. Karst.) Berch & + & 3.3 & 25.0 \\
\hline Glomus sp. 1 & - & 1.0 & 12.5 \\
\hline Glomus sp. 2 & - & 1.1 & 9.5 \\
\hline Glomus sp. 3 & - & 0.8 & 7.1 \\
\hline Gigaspora margarita W.N. Becker \& I.R. Hall & - & 1.8 & 18.5 \\
\hline Gigaspora sp. & - & 0.8 & 8.9 \\
\hline Scutellospora calospora C. Walker \& F.E. Sanders & - & 2.0 & 18.5 \\
\hline Scutellospora sp. 1 & - & 0.9 & 10.7 \\
\hline Scutellospora sp. 2 & - & 0.7 & 13.1 \\
\hline
\end{tabular}

Sporocarp status shown as + , observed; - not detected 
were mounted on glass slides in polyvinyl alcohol-lactoglycerol (PVLG) and PVLG + Melzer's reagent and then identified to species level using current taxonomic criteria (Morton and Redecker 2001) and information published by INVAM (http://www.invam.caf.wvu.edu).

Numbers and distribution of AM fungal spores

Species richness, spore density, frequency, and relative abundance of AM fungi were expressed as follows: spore density (SD), number of AM fungal spores in $100 \mathrm{~g}$ dry soil; species richness (SR), number of AM fungal taxa found in $100 \mathrm{~g}$ dry soil; relative abundance (RA), (number of spores of a species or genus/total spores $) \times 100$; and frequency $(\mathrm{F})$, (number of samples in which the species or genus was observed/total samples) $\times 100$.

Statistical analysis

The data were subjected to one-way ANOVA using SPSS software version 11.0. The differences in percent root length colonized, spore density, and species richness were separated by least significant difference (LSD) test for significantly different means in all taxa. The relationships between percentage of root length colonized and spore density and between percentage of root length colonized and species richness were analyzed by linear regression and correlation. Goodness of fit was assessed by simple correlation coefficients $(r)$ and degrees of freedom.

\section{Results}

\section{Colonization by AM fungi}

The AM status of the 28 Meliaceae species and varieties is shown in Table 2. Arbuscular mycorrhizal fungi colonized all plant species examined. However, there were significant differences among different host plants. The overall mean percentage of root length colonized was $55.5 \%$ and ranged widely from 10 to $95 \%$. Ill-defined arbuscules, typical of Paris-type mycorrhizae, vesicles, and hyphal coils were observed in the majority of plant samples collected (Table 2). Vesicles were present in 27 and hyphal coils in 26 of the Meliaceae species, but no typical Arum-type mycorrhizae were observed. There was no relationship between AM colonization values and soil properties analyzed.

Spore density and species richness of AM fungi

The spore densities in the rhizosphere of the Meliaceae taxa ranged from 46 to 1,499 per $100 \mathrm{~g}$ soil, with an average of 322. Significant differences were observed among rhizosphere soils of the different Meliaceae taxa. Spore densities of AM fungi in the rhizosphere of Trichilia sinensis were highest, and the lowest spore densities were observed in rhizosphere samples of Toona microcarpa (Table 2). The species richness of AM fungi in 28 Meliaceae species and varieties ranged from 3.7 in the rhizosphere of Trichilia connaroides to 13.5 in the rhizosphere of Toona sinensis, with a mean value of 7.3 (Table 2).

\section{Genera and species of AM fungi}

A total of 33 taxa representing five genera of AM fungi were distinguished in the samples from the 28 Meliaceae species and varieties. Among them, 24 (73\%) were identified at the species level and $9(27 \%)$ at the genus level. Of the 33 taxa, 9 belonged to the genus Acaulospora, 1 to Entrophospora, 18 to Glomus, 2 to Gigaspora, and 3 to Scutellospora. Sporocarps were observed in Glomus aggregatum, Glomus glomerulatum, and Glomus versiforme (Table 3).

\section{Relative abundance and frequency of AM fungi}

Relative abundance (RA) and frequency (F) of all the species of AM fungi are shown in Table 3. Spores of the genus Glomus were the most numerous both in RA and in $\mathrm{F}$, followed by the second most dominant genus, Acaulospora. The most abundant and most frequent AM fungal taxon present was Glomus claroideum N.C.Schenck \& G.S.Smith. The relative abundance of AM fungi varied from 0.7 (Scutellospora sp. 2) to 10\%, with an average of $3 \%$. The frequencies of AM fungi ranged from 6 to $56 \%$, with an average of $22 \%$.

\section{Discussion}

The present study has indicated the predominance of arbuscular mycorrhizae in the family Meliaceae in the tropical forests of Hainan island. This is in agreement with the observations made on other tropical forest tree species (Janos 1980; Högberg 1982; Sieverding 1991; Moyersoen et al. 1998; Andrade et al. 2000; Breuninger et al. 2000; Zhao et al. 2001; Muthukumar et al. 2003; Wubeta et al. 2003). Arbuscular mycorrhizal structures were observed in most of the plant species sampled in our survey. The frequency of occurrence of arbuscules was lower than that of vesicles and hyphal coils. One possible explanation is that Meliaceae may form typical Paris-type or intermediate-type mycorrhizae. This finding supports the results of a previous work that was restricted to only one genus of Meliaceae (summarized in Smith and Smith 1997) and extends the number of genera in the Meliaceae examined to 15 .

There were significant differences in the species richness and spore density of the AM fungi in the rhizopheres of the plants on Hainan island. Values for spore density are broadly in accord with the results of Zhao et al. (2001), which were high compared with those of Wubeta et al. 
(2003). The richness values were relatively high and varied with host plant species, but not in relation to soil properties. Other ecological factors could have affected the development and distribution of AM fungi, for example, seasonality, host-dependence, age of the host plants, sporulation capability of the AM fungi, and the dormancy and distribution patterns of AM fungal spores in soils (Koske and Halvorson 1981; Walker et al. 1982; Sylvia 1986; Koske 1987; Gemma and Koske 1988; Bever et al. 1996; Guadarrama and Alvarez-Sanchez 1999; Greipsson and El-Mayas 2000).

Arbuscular mycorrhizal fungi belonging to the genera Acaulospora and Glomus were dominant in the rhizopheres of the Meliaceae in our survey, with $82 \%$ of the AM fungi identified in these two genera. In contrast, Entrophospora, Gigaspora, and Scutellospora represented only 3,6 , and $9 \%$ of the species numbers. These results are consistent with other investigations conducted in tropical forests (Zhao 2000; Zhao et al. 2001; Muthukumar et al. 2003; Tawaraya et al. 2003).

No relationship was found between the percentage of root length colonized and spore density $(r=0.0158 ; n=168$; $p>0.05$ ). However, a positive correlation was observed between percentage of root length colonized and AM fungal species richness $(r=0.4813, n=168, p<0.001)$. These findings contrast with some previous studies in which no demonstrable relationship between these variables was reported (Brundrett 1991; Zahka et al. 1995; Brundrett et al. 1996), but they are consistent with others (Muthukumar and Udaiyan 2000; Muthukumar et al. 2003). Detailed studies on the relationship between root colonization and spore density and between root colonization and species richness in the rhizopheres of Meliaceae species merit further investigation. Future studies using molecular methods may also reveal additional diversity in AM fungi associated with roots of Meliaceae that conventional microscope techniques may not have detected.

Acknowledgements This work was funded by the Natural Science Foundation of China (Project 30370818) and the Royal Society (Project 15360)

\section{References}

Andrade ACS, Queiroz MH, Hermes RAL, Oliveira VL (2000) Mycorrhizal status of some plants of the Araucaria forest and the Atlantic rainforest in Santa Catarina, Brazil. Mycorrhiza 10:131-136

Bever JD, Morton JB, Antonovics J, Schultz PA (1996) Hostdependent sporulation and species diversity of arbuscular mycorrhizal fungi in a mown grassland. J Ecol 84:71-82

Biermann B, Linderman RG (1981) Quantifying vesicular-arbuscular mycorrhizae: a proposed method towards standardization. New Phytol 87:63-67

Breuninger M, Einig W, Magel E, Cardoso E, Hampp R (2000) Mycorrhiza of Brazil pine [Araucaria angustifolia (Bert. O. Ktze.)]. Plant Biol 2:4-10
Brundrett M (1991) Mycorrhizas in natural ecosystems. Adv Ecol Res 21:171-313

Brundrett M, Abbott L, Jasper D, Malajczuk N, Bougher N, Brennan K, Ashwath N (1995) Mycorrhizal associations in the alligator rivers region. Part II results of experiments. Final report. Office of the Supervising Scientist, Jabiru N.T., Australia

Brundrett MC, Ashwath N, Jasper DA (1996) Mycorrhizas in the Kakadu region of tropical Australia. I. Propagules of mycorrhizal fungi and soil properties in natural habitats. Plant Soil 184:159-171

Cairney JWG (2000) Evolution of mycorrhiza systems. Naturwissenschaften 87:467-475

Chen BY (1995) Geographical distribution of Chinese Meliaceae. J Trop Subtrop Bot 3:12-22

Cheplogoi PK, Mulholland DA (2003) Limonoids from Turraea parvifolia (Meliaceae). Biochem Syst Ecol 31:799-803

Dalpe Y (1993) Vesicular-arbuscular mycorrhiza. In: Carter MR (ed) Soil sampling and methods of analysis. Lewis Publishers, Boca Raton, FL, pp 287-301

Gemma JN, Koske RE (1988) Seasonal variation in spore abundance and dormancy of Gigaspora gigantea and in mycorrhizal inoculum potential of a dune soil. Mycologia 80:211-216

Greipsson S, El-Mayas H (2000) Arbuscular mycorrhizae of Leymus arenarius on coastal sands and reclamation sites in Iceland and response to inoculation. Restor Ecol 8:144-150

Guadarrama P, Alvarez-Sanchez FJ (1999) Abundance of arbuscular mycorrhizal fungi spores in different environments in a tropical rain forest, Veracruz, Mexico. Mycorrhiza 8:267-270

Hartnett DC, Wilson GWT (1999) Mycorrhizae influence plant community structure and diversity in tallgrass prairie. Ecology 80:1187-1195

Högberg P (1982) Mycorrhizal associations in some woodland and forest trees and shrubs in Tanzania. New Phytol 92:407-415

Janos DP (1980) Vesicular-arbuscular mycorrhizae affect lowland tropical rain forest plant growth. Ecology 61:151-162

Johnson NC, Graham JH, Smith FA (1997) Functioning of mycorrhizal associations along the mutualism-parasitism continuum. New Phytol 135:575-586

Klironomos JN, McCune J, Hart M, Neville J (2000) The influence of arbuscular mycorrhizae on the relationship between plant diversity and productivity. Ecol Lett 3:137-141

Koske RE (1987) Distribution of VA mycorrhizal fungi along a latitudinal temperature gradient. Mycologia 79:55-68

Koske RE, Halvorson WL (1981) Ecological studies of vesiculararbuscular mycorrhizae in a barrier sand dune. Can J Bot 59: $1413-1422$

Koske RE, Tessier B (1983) A convenient, permanent slide mounting medium. Newsl Mycol Soc Am 34:59

McGonigle TP, Miller MH, Evans DG, Fairchild GL, Swan JA (1990) A new method which gives an objective measure of colonization of roots by vesicular arbuscular mycorrhizal fungi. New Phytol 115:495-501

Morton JB, Redecker D (2001) Two new families of Glomales, Archaeosporaceae and Paraglomaceae, with two new genera Archaeospora and Paraglomus, based on concordant molecular and morphological characters. Mycologia. 93:181-195

Moyersoen B, Fitter AH, Alexander IJ (1998) Spatial distribution of ectomycorrhizas and arbuscular mycorrhizas in Korup National Park rain forest, Cameroon, in relation to edaphic parameters. New Phytol 139:311-320

Muthukumar T, Udaiyan K (2000) Arbuscular mycorrhizas of plants growing in the Western Ghats region, Southern India. Mycorrhiza 9:297-313

Muthukumar T, Sha LQ, Yang XD, Cao M, Tang JW, Zheng Z (2003) Mycorrhiza of plants in different vegetation types in tropical ecosystems of Xishuangbanna, southwest China. Mycorrhiza 13:289-297 
Omar S, Zhang J, MacKinnon S, Leaman D, Durst T, Philogene BJR, Arnason JT, Sanchez-Vindas PE, Poveda L, Tamez PA, Pezzuto JM (2003) Traditionally-used antimalarials from the Meliaceae. Curr Top Med Chem 3:137-139

Read DJ (1994) Plant-microbe mutualisms and community structure. In: Schulze ED, Mooney HA (eds) Biodiversity and ecosystem function. Springer, Berlin Heidelberg New York, pp 181-209

Sanders IR, Clapp JP, Wiemken A (1996) The genetic diversity of arbuscular mycorrhizal fungi in natural ecosystems: a key to understanding the ecology and functioning of the mycorrhizal symbiosis. New Phytol 133:123-134

Sieverding E (1991) Vesicular-arbuscular mycorrhiza management in tropical agroecosystems. Deutsche Gesellschaft für Technische Zusammenarbeit, Eschborn, Germany

Smith SE, Read DJ (1997) Mycorrhizal symbiosis, 2nd edn. Academic, London

Smith FA, Smith SE (1997) Structural diversity in (vesicular)arbuscular mycorrhizal symbioses. New Phytol 137:373-388

Sylvia DM (1986) Spatial and temporal distribution of vesiculararbuscular mycorrhizal fungi associated with Uniola paniculata in Florida foredunes. Mycologia 78:728-734

Tawaraya K, Takaya Y, Turjaman M, Tuah SJ, Limin SH, Tamai Y, Cha JY, Wagatsuma T, Osaki M (2003) Arbuscular mycorrhizal colonization of tree species grown in peat swamp forests of Central Kalimantan, Indonesia. For Ecol Manag 182:381-386 van der Heijden MGA, Boller T, Wiemken A, Sanders IR (1998a) Different arbuscular mycorrhizal fungi species are potential determinants of plant community structure. Ecology 79:20822091

van der Heijden MGA, Klironomos JN, Ursic M, Moutoglis P, Streitwolf-Engel R, Boller T, Weimken A, Sanders IR (1998b) Mycorrhizal fungal diversity determines plant biodiversity, ecosystem variability and productivity. Nature 396:69-72

Walker C, Mize CW, McNabb HS (1982) Populations of endogenous fungi at two locations in central Iowa. Can J Bot 60:25182529

Wubeta T, Kottke I, Demel T, Oberwinkler F (2003) Mycorrhizal status of indigenous trees in dry Afromontane forests of Ethiopia. For Ecol Manag 179:387-399

Zahka GA, Baggett KL, Wong BL (1995) Inoculum potential and other VAM fungi parameters in four sugar maple forests with different levels of stand dieback. For Ecol Manag 75:123-134

Zhao ZW (2000) The arbuscular mycorrhizas of pteridophytes in Yunnan, southwest China: evolutionary interpretations. Mycorrhiza 10:145-149

Zhao ZW, Xia YM, Qin XZ, Li XW, Cheng LZ, Sha T, Wang GH (2001) Arbuscular mycorrhizal status of plants and the spore density of arbuscular mycorrhizal fungi in the tropical rain forest of Xishuangbanna, southwest China. Mycorrhiza 11:159162 